VERSITA

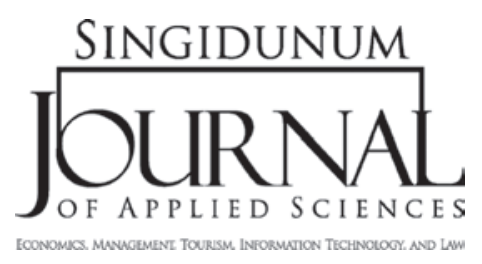

SJAS 2014, 11 (1): 74-83

ISSN 2217-8090

UDK: $336.761 ; 005.334$

DOI: $10.5937 /$ sjas $11-5820$

Review paper/Pregledni naučni rad

\title{
OPTIONS, GREEKS, AND RISK MANAGEMENT
}

\author{
Jelena Paunović ${ }^{1, *}$ \\ ${ }^{1}$ Wiener Städtische osiguranje a.d.o. Belgrade \\ 1 Trešnjinog cveta Street, Belgrade, Serbia
}

\begin{abstract}
:
Options are financial derivatives representing a contract which gives the right to the holder, but not the obligation, to buy or sell an underlying asset at a pre-defined strike price during a certain period of time. These derivative contracts can derive their value from almost any underlying asset or even another derivative: stock-options, options on bonds, swap options (options on swaps), weather options, real options and many others. Options have existed for a long period of time but they became widely popular after Fisher Black, Myron Scholes and Robert Merton developed a theoretical pricing model in 1973 known as the Black-Scholes model. Options became a standardized product traded on the Chicago board of options Exchange (CBOT) through the clearing house guarantees. Nowadays, options are both market and OTC (over the counter) traded and are mainly used for portfolio hedging and speculation.

In this paper I am going to study market risk management from the perspective of options trader, and I will show how to describe the risk characteristics of plain vanilla European stock options contracts by going through the "Greeks" which are defined as quantities that represent option's sensitivity to risk. Finally, I will construct portfolios that will eliminate these risks.
\end{abstract}
Key words:
financial derivatives,
OTC market,
hedging,
risk,
speculations,
Black-Scholes model,
Greeks.

\section{THE BLACK-SCHOLES MODEL}

Options are financial derivative contracts that give the right to the holder, but not the obligation, (Jeremić, 2009) to buy or sell an underlying stock at a pre-defined strike price $\mathrm{K}$ within a certain time period. Fisher Black, Myron Scholes and Robert Merton (1973) provide a formula that will price any European option assuming a particular model for the underlying price dynamics (they won the Nobel Prize).The Black-Scholes (Black and Scholes,1972) model was derived out of the following assumptions:
- Stock prices follow a geometric Brownian motion, volatility is constant, there are no transaction costs or taxes, trade is continuous, there are no limits on short-selling, no dividends, and risk free interest rate is constant (Nations, 2012).

Most of these assumptions can be relaxed in order to describe the real world better.

In this model, stock prices move continuously and the pricing argument is exactly the same replication argument as in the binomial trees option's pricing (Živković and Šoškić, 2007). 
If we consider all the above - mentioned assumptions, their model allows us to solve the price of the option in a particularly elegant way.

Six factors are affecting the price of an option:

- the spot price of the stock at the moment T denoted as $\mathrm{S}_{\mathrm{t}}$.

- the Exercise or strike price denoted as $\mathrm{K}$, at which the financial security can be bought or sold.

- the option expiration time denoted as T.

- the Volatility of the underlying stock denoted as $\sigma$.

The option price is a function of all these variables so the European call can be written as follows:

$$
\text { Call Price }=C(S(t), K, T, r, \sigma) \text {. }
$$

The Black-Scholes formula for the value of a European call option on a non-dividend paying stock is given by (Kolb, 2003):

$$
c^{B S}\left(S_{t}, K, T, r, \sigma\right)=S_{t} N\left(d_{1}\right)-K e^{-r(T-t)} N\left(d_{2}\right) .
$$

$\mathrm{N}(\mathrm{x})$ is the probability that a $\mathrm{N}(0,1)$ random variable is less than $\mathrm{x}$, and

$$
\begin{aligned}
& d_{1}=\frac{\ln \left(S_{t} / K\right)+\left(r+0.5 \sigma^{2}\right)(T-t)}{\sigma \sqrt{T-t}}, \\
& d_{2}=\frac{\ln \left(S_{t} / K\right)+\left(r+0.5 \sigma^{2}\right)(T-t)}{\sigma \sqrt{T-t}} \\
& d_{2}=d_{1}-\sigma \sqrt{T-t} .
\end{aligned}
$$

$\mathrm{Ln}$ is the natural logarithm; $\sigma$ is the volatility of the continuously compounded return of the stock. If we re-write

$$
\begin{aligned}
& c^{B S}\left(S_{T}, K, T, r, \sigma\right)=\underbrace{N\left(d_{1}\right)}_{\Delta} S t \underbrace{-K e^{-r(T-t)} N\left(d_{2}\right)}_{B} \\
& \text { as } C^{B S}\left(S_{t}, K, T, r, \sigma\right)=\Delta S_{t}+B,
\end{aligned}
$$

we can see a similarity to the one-period replication model of the binomial trees.

Actually, the Black-Scholes is derived by no arbitrage (Mullaney, 2009), as it replicates an option by a dynamic portfolio of a stock and a bond. It is the limit to the binomial model when the number of branches goes to infinity. The detailed derivation of the Black-Scholes model and the binomial tree model falls out of the scope of this paper. We can see from what is given above that the call option can be replicated by buying a delta amount of stock and by selling $B$ amount of bonds. In this case $N\left(d_{1}\right)$ is the "hedge ratio" delta and it gives the number of shares of the stock to hold at time $t$ in order to replicate the call.

The key variable which determines the option price is volatility, $\sigma$.

The strike and the maturity are determined by the contract, the underlying asset price is monitored, and the risk free rate is easily approximated by, for instance, LIBOR or by the overnight interest rate swap. Certainly, Black-Scholes options prices are not what we shall see in the market. If the model was entirely correct, options with the same expiration date for the same stock would have the same implied volatility which is not to be encountered on the market. However, the traders use the implied volatility to calculate the price of options. The observed relation between the implied (Black and Scholes,1972) volatility and the strike price for a given maturity is called the volatility smile. The relation between the implied volatility and maturity for a given strike is called the structure of volatility.

We've just had a quick reminder of the BlackScholes model and its assumptions; so we are now ready to start analyzing risk exposures and the characteristics of the main risks associated with a more complex portfolio of underlying stock positions.

\section{OPTIONS AND RISK MANAGEMENT}

The following example will be used throughout this paper:

Let's suppose we are trading options for J.P. Morgan and we write an (at-the-money) European call for $\$ 5$ with $\mathrm{T}=10$ weeks. The underlying stock is traded at $\$ 50$, sigma $=50 \%$, and the risk-free rate is $3 \%$. The Black-Scholes model gives us the price of the call option: $\$ 4.5$.

In order to make a risk-free $\$ 0.5$ profit we could buy the same option for $\$ 4.5$ elsewhere or spend $\$ 4.5$ on a replicating portfolio (by buying a synthetic option for example) that has the same payoff.

This is possible in theory, however, in practice, perfect replication of the option's payoff is not real. We cannot perfectly hedge all the risk associated with the call we have just written.

That could be done if the binomial tree model perfectly described the stock price dynamics (which is not the case in the real world) and if we traded without transaction costs (which is also impossible). 
Unfortunately, the lognormal distribution of the price dynamics in the Black-Scholes model does not describe the stock price dynamics perfectly.

On the other hand, in the real world, we can't trade continuously (Jonson, 2007) - the transaction costs can be substantial and the volatility of the underlying risk free stock isn't constant as assumed by the theoretical Black-Scholes model. If the Black-Scholes model was perfect, the options markets wouldn't even exist, as each option would have only one real price. In practice, options traders behave in the following way - they identify different risk sources that change the value of our call: the stock price $S(t)$, the time $T$, the volatility and the interest rate $r$.

Then, they form an approximate replicating portfolio for the written call option. The value of this portfolio should change by about the same amount as that of the option (at least for small changes in the factors). In order to determine how sensitive the options are to the particular risk source one should look at the "Greeks" options (Hull, 2002) - quantities denoted by Greek letters representing options' sensitivities to risk. They are the key to options risk management.

\section{THE "GREEKS”}

In order to construct the approximate replicating portfolio, we have to know by how much the value of the option changes as various risk factors change (Hull, 2011).

Using calculus, for small changes in the risk factors, the value of the call option changes by:

$$
d C=\underbrace{\frac{\partial C}{\partial S}}_{\text {Delta }} d S+\underbrace{\frac{1}{2} \frac{\partial^{2} C}{\partial S^{2}}}_{\text {Gamma }}(d S)^{2}+\underbrace{\frac{\partial C}{\partial t} d t}_{\text {Theta }}+\underbrace{\frac{\partial C}{\partial \sigma} d \sigma}_{\text {Vega }}+\underbrace{\frac{\partial C}{\partial r} d r}_{\text {Rho }}, \text { (6) }
$$

or using the Greek symbols $\Delta, \Gamma, \Theta, v$ and $p$, we have:

$$
d C=\Delta_{c} d S+\frac{1}{2} \Gamma_{c}(d S)^{2}+\Theta_{c} d t+v_{c} d \sigma+p_{c} d r,
$$

These Greeks depict the market risk associated with the option.

In order to understand the following examples, we are first going to compute the $\Delta, \Gamma, \Theta, v$ and $p$, for the underlying stock:

$\Delta_{s}=\frac{\partial S_{t}}{\partial S_{t}}=1, \Gamma_{s}=\frac{\partial \Delta_{s}}{\partial S_{t}}=0^{1}, \Theta_{s}=\frac{\partial S_{t}}{\partial_{t}}=0$, $v_{s}=\frac{\partial S_{t}}{\partial \sigma}=o, p_{s}=\frac{\partial S_{t}}{\partial r}=0$.

Thus, a stock has just a delta equal to 1 and all the other Greeks are zero valued.

Now, for a European call option, this is how its price changes when only one factor varies whereas the others are fixed:

- The Delta $(\Delta)$ describes the derivative's sensitivity to the price of the underlying security $S$.

We can see from the Black-Scholes formula that the delta of call and put option is:

$$
\Delta_{c}=\frac{\partial C}{\partial S}=N\left(d_{1}\right)>0, \Delta_{p}=\frac{\partial P}{\partial S}=-N\left(-d_{1}\right)<0,
$$

and we can see that

$$
\Delta_{c} \rightarrow 0 \text { as } S \rightarrow 0 \text { and } \Delta_{c} \rightarrow 1 \text { as } S \rightarrow \infty
$$

A delta of a call option typically looks like the graph given in the following chart (Hull, 2002):
Delta vs. Underlying price
$T=1$ week, 1 month, and 1 quarter

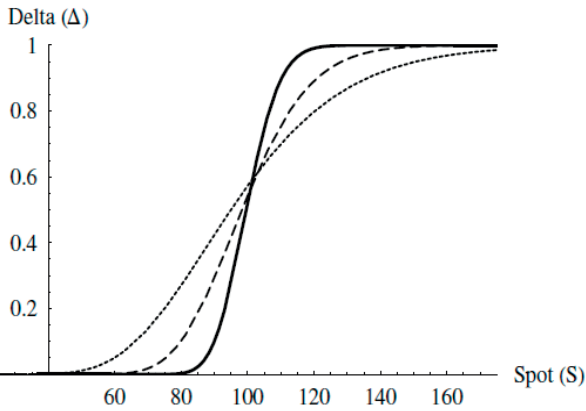

Delta vs. Time-to-Expiration ITM, ATM, OTM

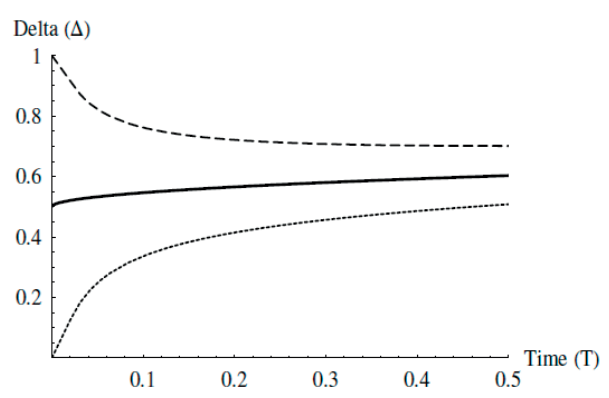

The above-given charts make the following assumptions: delta, gamma, theta, rho and vega are seen as a function of time-to maturity, for three different levels of moneyness (with $K=100$ (the solid line, at the money), $K=80$ (dashed line, in the money) and $K=120$ (dotted line, OTM)). In all these examples $S=100$, sigma $=0.56$, and $r=5 \%$. 
The Gamma describes the derivative's convexity and is given by:

$$
\Gamma_{c}=\frac{\partial \Delta_{c}}{\partial S}=\frac{\partial d_{1}}{\partial S} N^{\prime}\left(d_{1}\right)=\frac{N^{\prime}\left(d_{1}\right)}{S_{\sigma} \sqrt{T-t}}>0 .
$$

The Gamma of the call option is always equal to the gamma of the put:

$$
\Gamma_{p}=\frac{-\partial\left(-d_{1}\right)}{\partial S} N^{\prime}\left(-d_{1}\right)=\Gamma_{c} .
$$

We can see that

$$
\Gamma \rightarrow 0 \text { as } S \rightarrow 0 \quad \Gamma \rightarrow 0 \text { as } S \rightarrow \infty \text {, }
$$

$\Gamma$ is high when $S \approx K$.

In fact, Gamma tells us how much delta we gain as the underlying stock rises. It also reveals another important thing and that is by how much a deltahedged derivative becomes unhedged (Ross et al., 2012a). We'll deal with this in further details at the end of the paper when we'll be building hedging portfolios.

A gamma of a call option typically looks like the graph given in the following chart:

Gamma vs. Underlying price

$\mathrm{T}=1$ week, 1 month, and 1 quarter

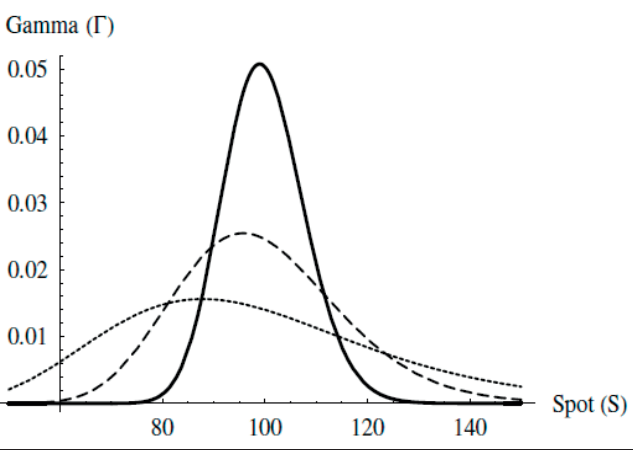

Gamma vs. Time-to-Expiration ATM, OTM, ITM

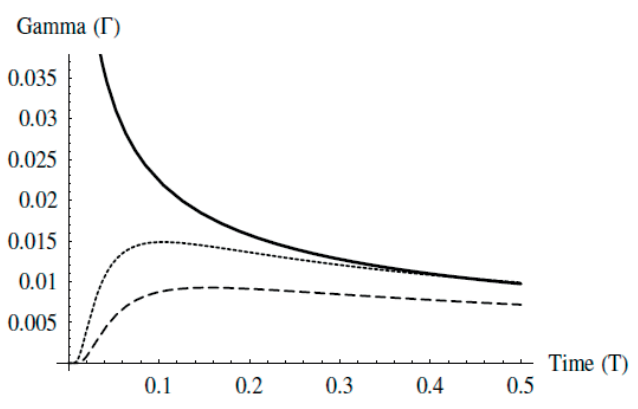

The Theta describes a derivative's sensitivity to the time to maturity (T). It captures the time-decay and it is given by the following formula using Black-Scholes:

$$
\begin{aligned}
& \Theta_{c}=\frac{\partial c}{\partial t}=\frac{-\partial}{\partial(T-t)}\left(S N\left(d_{1}\right)-K e^{-r(T-t)} N\left(d_{2}\right)\right) \\
& \Theta_{c}=-S \frac{\partial N\left(d_{1}\right)}{\partial(T-t)}+K e^{-r(T-t)} \frac{\partial N\left(d_{2}\right)}{\partial(T-t)}-r K e^{-r(T-t)} N\left(d_{2}\right) .
\end{aligned}
$$

When simplified, it becomes:

$$
\begin{aligned}
& S N^{\prime}\left(d_{1}\right)=\frac{S e^{-\left(d_{2}+\sigma \sqrt{T-t)^{2}} / 2\right.}}{\sqrt{2 \pi}} \\
& S N^{\prime}\left(d_{1}\right)=S N^{\prime}\left(d_{2}\right) e^{-\sigma \sqrt{T-t)} d 2-\sigma^{2}(T-t) / 2}=K e^{-r(T-t)} N^{\prime}\left(d_{2}\right),
\end{aligned}
$$

and with

$$
\frac{\partial\left(d_{1}-d_{2}\right)}{\partial(T-t)}=\frac{\partial(\sigma \sqrt{T-t})}{\partial(T-t)}=\frac{\sigma}{2 \sqrt{T-t}} .
$$

Taking them together we get:

$$
\Theta c=\frac{-N^{\prime}\left(d_{1)} \sigma S\right.}{2 \sqrt{T-t}}-r K e^{-r(T-t)} N\left(d_{2}\right)<0 .
$$

As theta is negative all the time, the value of the call decreases as time elapses which makes sense (Ross et al., 2012b).

However, for the put option we have to identify the put-call parity:

$$
\begin{aligned}
& \Theta p=\frac{\partial(C-f)}{\partial t}=\Theta c+\frac{\partial f}{\partial(T-t)} \\
& \Theta p=\frac{-N^{\prime}\left(d_{1)} \sigma S\right.}{2 \sqrt{T-t}}+r K e^{-r(T-t)} N\left(-d_{2}\right) .
\end{aligned}
$$

The first term of the theta (put) is negative because the variance of the stock price at maturity $\mathrm{T}$ decreases over time (Augen, 2011).

The second term is positive because the present value of the strike grows with less time to maturity. The put receives the strike, so this tends to make the put more valuable as time goes by. A theta of a call option typically looks like the graph given in the following chart: 
Theta vs. Underlying price

$\mathrm{T}=1$ week, 1 month, and 1 quarter

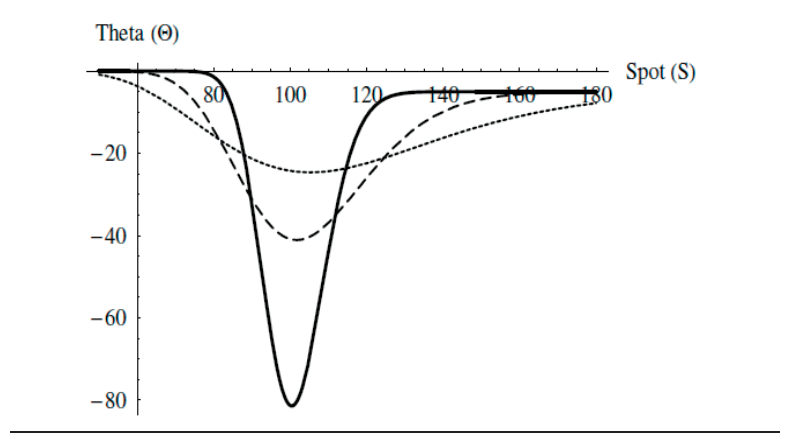

Theta vs. Time-to-Expiration

ATM, OTM, ITM

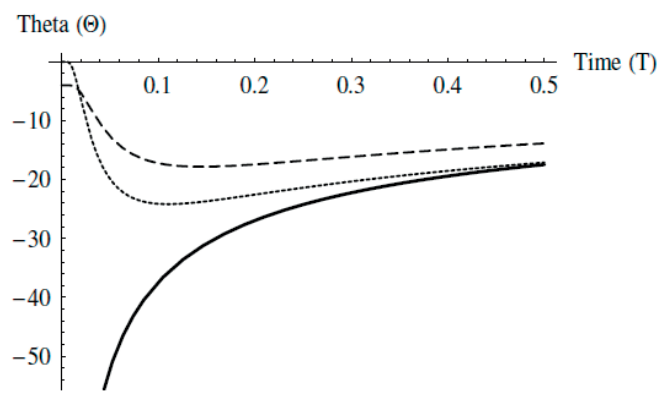

The Vega describes the option's sensitivity to the volatility of the underlying stock and is given by:

$$
\begin{aligned}
& v_{c}=\frac{\partial C}{\partial \sigma}=S \sqrt{T-t} N^{\prime}\left(d_{1}\right)>0, \\
& v_{p}=\frac{\partial p}{\partial \sigma}=v_{c} .
\end{aligned}
$$

We can easily see that:

$v \approx 0$ for $S<K$,

$v$ is the largest for $S \approx K e^{-r(T-t)}$,

$v \approx 0$ for $S>K$.

The Vega is really valuable because the BlackScholes model is assumes/implies constant volatility. Volatility traders use complex statistical models (ARIMA, GARCH etc.) to predict the options implied volatility and thus make decisions if an option is over or under-valued (Fontanills, 2005). The Vega of a call option typically looks like the graph given in the following chart:

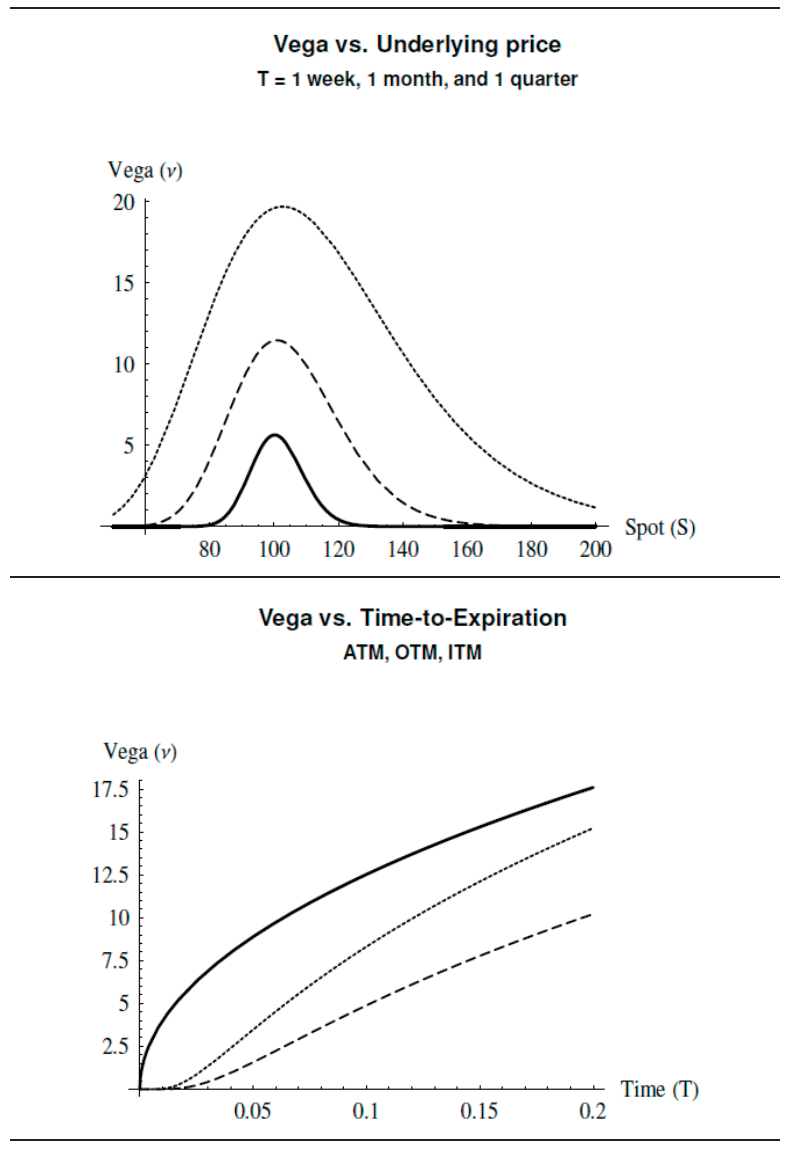

The Rho describes the option's sensitivity to the risk free interest (Natenberg, 1994) rate changes and is given by:

$$
\begin{aligned}
& p_{c}=\frac{\partial}{\partial r}\left(S N\left(d_{1}\right)-K e^{-r(T-t)} N\left(d_{2}\right)\right) \\
& p_{c}=S \frac{\partial N\left(d_{1}\right)}{\partial r}-K e^{-r(T-t)} \frac{\partial N\left(d_{2}\right)}{\partial r}+(T-t) K e^{-r(T-t)} N\left(d_{2}\right) .
\end{aligned}
$$

Now we have:

$$
\frac{\partial N\left(d_{1}\right)}{\partial r}=\frac{\partial d_{1}}{\partial r} N^{\prime}\left(d_{1}\right),
$$

and

$$
\frac{\partial N\left(d_{2}\right)}{\partial r}=\frac{\partial\left(d_{1}-\sigma \sqrt{T-t}\right)}{\partial r} N^{\prime}\left(d_{2}\right)=\frac{\partial d_{1}}{\partial r} N^{\prime}\left(d_{2}\right),
$$

and

$S N^{\prime}\left(d_{1}\right)=K e^{-r(T-t)} N^{\prime}\left(d_{2}\right)$,

so finally we get:

$$
p_{c}=(T-t) K e^{-r(T-t)} N\left(d_{2}\right)>0 \text {. }
$$


By put-call parity:

$$
\begin{aligned}
& p_{p}=\frac{\partial\left(C-S+K e^{-r(T-t)}\right.}{\partial r} \\
& p_{p}=p_{c}-(T-t) K e^{-r(T-t)} \\
& p_{p}=-(T-t) K e^{-r(T-t)} N\left(-d_{2}\right)<0 .
\end{aligned}
$$

The value of the call always increases when interest rates rise (Passarelli, 2011), while the current value of the strike price $\mathrm{K}$ drops. The opposite is true for the puts.

The Rho of a call option typically looks like the graph given in the following chart:

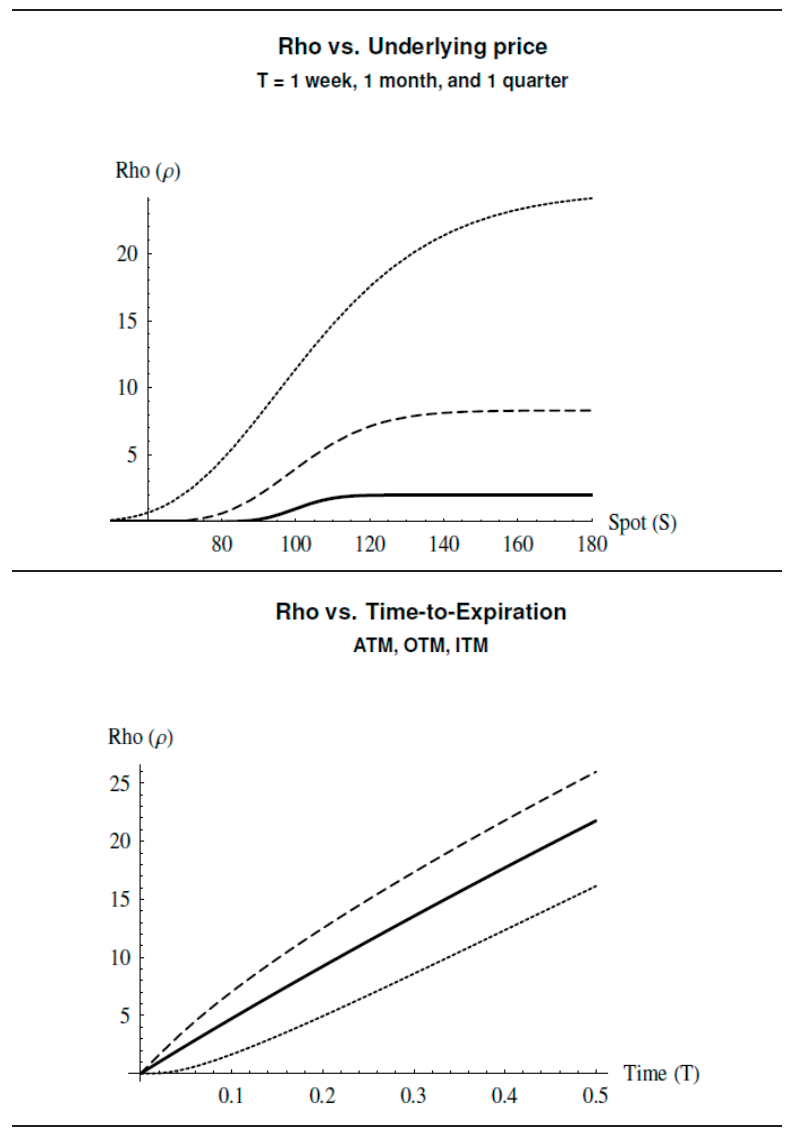

The quantities we have just derived are the main sources of an option risk.

However, there are some other "Greeks" such as The Lambda, the Volga, and the Vanna, which are much less common and measure the delta per invested dollar, the second order sensitivity to volatility and the sensitivity of delta to volatility, respectively.

For a call option, they are given by

$$
\lambda_{c}=\frac{\Delta_{c}}{C}, \frac{\partial^{2} C}{\partial \sigma^{2}}=\frac{\partial v_{c}}{\partial \sigma} \text { and } \frac{\partial^{2} C}{\partial \sigma \partial S}=\frac{\partial \Delta_{c}}{\partial \sigma} .
$$

\section{RISK MANAGEMENT WITH THE GREEKS}

The basic idea of portfolio hedging is that the value of a portfolio can be made invariant to the factors affecting it. For example let's say we have a portfolio that consists of three assets (Vine, 2011):

$V=n_{1} A_{1}+n_{2} A_{2}+n_{3} A_{3}$,

with: $\mathrm{V}$ the total value of the portfolio (McDonald, 2009), n(i) the number of shares of asset I and A(i) the market value of one share of asset $i$.

Then the sensitivity of this portfolio to some factor $\mathrm{x}$ is given by the first derivative:

$$
\frac{\partial V}{\partial x}=n_{1} \frac{\partial A_{1}}{\partial x}+n_{2} \frac{\partial A_{2}}{\partial x}+n_{3} \frac{\partial A_{3}}{\partial x} .
$$

The aim of $\mathrm{x}$-hedging is to pick the $\mathrm{n}(\mathrm{i})$ so that the value of the entire portfolio remains constant when the factor $\mathrm{x}$ changes, which is equal as picking the $n(i)$ so that:

$$
\frac{\partial V}{\partial x}=n_{1} \frac{\partial A_{1}}{\partial x}+n_{2} \frac{\partial A_{2}}{\partial x}+n_{3} \frac{\partial A_{3}}{\partial x}=0 .
$$

When $\mathrm{x}$ changes by one unit, the value of the entire portfolio will stay approximately constant. What is important to notice here is that it takes $n$ assets to hedge against $n-1$ sources of risk. If we have 3 assets in the portfolio we can only hedge away two risks (Augen, 2008).

\section{DELTA HEDGING}

A portfolio is called Delta neutral or delta hedged if the delta of the portfolio is equal to zero. Similar to our previous example but this time with $\mathrm{x}=\mathrm{S}(\mathrm{t})$. The portfolio will be delta neutral if we pick the number of shares $n(i)$ so that:

$$
\begin{aligned}
& \Delta_{\text {portfolio }}=\frac{\partial V}{\partial s}=n_{1} \frac{\partial A_{1}}{\partial s}+n_{2} \frac{\partial A_{2}}{\partial s}+n_{3} \frac{\partial A_{3}}{\partial s} \\
& \Delta_{\text {portfolio }}=n_{1} \Delta_{1}+n_{2} \Delta_{2}+n_{3} \Delta_{2}=0 .
\end{aligned}
$$

If we create such portfolio, it is going to be invariant to changes in underlying stock price $S(t)$.

Coming back to our J.P. Morgan example from the beginning of the paper where we wrote the call option for $\$ 5$ : 
Let's say we have

$S=50, K=50, T-t=\frac{10}{52}, \sigma=0.50$ and $r=0.03$.

In order to delta-hedge this option, we shall first compute the delta with the Black-Scholes model - we get $\Delta_{C}=0.554$. As we have written the call, and knowing that the delta of the stock is equal to 1 , we will buy the shares such as

$n_{s} \times 1-0.554=0 \Leftrightarrow n_{s}=\Delta_{\mathrm{S}}=0.554$

shares of the underlying stock.

\section{GAMMA HEDGING}

A portfolio is called Gamma neutral or Gamma hedged if the Gamma of the portfolio is equal to zero. Similar to our previous example with 3 assets, we have $\mathrm{x}=\mathrm{S}(\mathrm{t})$. The portfolio total gamma is given by the second derivative in respect to the underlying stock $\mathrm{S}(\mathrm{t})$ :

$$
\begin{aligned}
\Gamma_{\text {portfolio }} & =\frac{\partial^{2} V}{\partial S^{2}}=\frac{\partial \Delta_{\text {portfolio }}}{\partial S} \\
\Gamma_{\text {portfolio }} & =n_{1} \frac{\partial A_{1}}{\partial S}+n_{2} \frac{\partial A_{2}}{\partial S}+n_{3} \frac{\partial A_{3}}{\partial S} \\
\Gamma_{\text {portfolio }} & =n_{1} \Gamma_{1}+n_{2} \Gamma_{2}+n_{3} \Gamma_{2} .
\end{aligned}
$$

We've previously seen that when we shorten the money call for $\$ 4.5$ and go long 0.554 shares, our portfolio will be delta hedged. Now the problem with delta hedging is only the following:

- If the underlying stock $S(t)$ makes a little move from $\$ 50$ to $\$ 51$, the value of the call $\mathrm{C}$ will go from $\mathrm{C}(50,50,10 / 52,0.50,0.03)=$ 4.498 to $\mathrm{C}(51,50,10 / 52,0.50,0.03)=5.070$.

Our portfolio will get a slight loss of $0.554(51$ $50)-(5.070-4.498)=-0.018 \$$.

- If the underlying $S$ makes a bigger move from $\$ 50$ to $\$ 60$, the value of our call will then go from $C(50,50,10 / 52,0.50,0.03)=4.498 \$$ to $\mathrm{C}(60,50,10 / 52,0.50,0.03)=11.541 \$$

- In the second case, the value of our portfolio would then get a more significant loss of $0.554(60-50)-(11.541-4.498)=1.54 \$$ for $\mathrm{a}$ $\$ 10$ increase of the underlying stock.

Our delta hedged position still has a considerable risk exposure for a large move in the underlying stock. This is where gamma hedging becomes interesting because it can improve the quality of the hedge.

\section{DELTA AND GAMMA HEDGING}

However, if we want to do both, gamma and delta hedge, we would need to buy another option because the stock has 0 gamma, as it was seen before (Cottle, 2006), for example a call with the strike $K=55 \$$.

To have both the gamma and the delta of the portfolio equal to zero we have to solve the following system of equations:

$$
\begin{aligned}
& n_{s} \Delta_{s}+n_{c_{55}} \Delta_{c_{55}}+n_{c_{50}} \Delta_{c_{50}}=0, \\
& n_{s} \Gamma_{s}+n_{c_{55}} \Gamma_{c_{55}}+n_{c_{50}} \Gamma_{c_{50}}=0 .
\end{aligned}
$$

The Black-Scholes model gives us:

$$
\Gamma_{c_{50}}=0.0361, \Delta_{c_{50}}=\text {, }
$$

and

$$
\Delta_{c_{55}}=\mathbf{B} \quad, \Gamma_{c_{55}}=\mathbf{C}
$$

By solving the system of equations we get:

$$
n_{s}=\mathbb{B} \quad \text { and } n_{c_{55}}=\mathbb{1} \text {, }
$$

which is the number of stock and call options with $\$ 55$ strike that would make our portfolio both delta and gamma neutral.

In this case if the underlying stock $S$ makes a little move from $\$ 50$ to $\$ 51$ (Bodie et al., 2010c), the portfolio would look as follows:

$\mathrm{C}_{50}(51)-\mathrm{C}_{50}(50)=5.067-4.498=0.569$

for the call with $\mathrm{K}=50 \$$ and

$\mathrm{C}_{55}(51)-\mathrm{C}_{55}(50)=3.002-2.602=0.400$

for the call with $\mathrm{K}=55 \$$.

The total value of the portfolio will increase by:

$0.158 \cdot 10+1.307 \cdot 5.501-1 \cdot 7.084=0.201 \$$

which is a very good hedge.

Now if the underlying stock $S$ makes a bigger move from $\$ 50$ to $\$ 60$ (Bodie et al., 2010a), the portfolio would look as follows:

$\mathrm{C}_{50}(60)-\mathrm{C}_{50}(50)=11.581-4.498=7.084$

for the call $\mathrm{K}=50 \$$ and

$\mathrm{C}_{55}(60)-\mathrm{C}_{55}(50)=8.104-2.602=5.501$

for the call $\mathrm{K}=55 \$$.

The total value of the portfolio will increase by:

$0.158 \cdot 10+1.037 \cdot 5.501-1 \cdot 7.084=0.201 \$$,

which is much less than if we only delta hedged the portfolio (the variation would've been \$1.55). 
However, in order to do this hedge it should not be forgotten that it takes 3 assets to form such portfolio.

\section{VEGA, THETA AND RHO HEDGING}

The mechanics of these hedging strategies are similar to Delta and Gamma hedging. Instead of equating the delta to zero, we are going to set Rho or Vega equal to zero (Cohen, 2005). These Greeks are important but less important than the other two Greeks mentioned before. We can construct portfolios that have pure exposures to individual Greeks by hedging all the other risks away (Sincere, 2006). For example, if we only want exposure to Vega that would mean that we will be "trading volatility".

\section{THE PRICE OF GREEKS}

Each one of these risk exposures has its own price (Passarelli, 2012). The simplest example would be to price the cost of a unit exposure to delta.

- As the underlying stock $S$ is a pure exposure to delta, one unit of delta would then cost the price of the underlying stock $S(t)$.

- If we want to price the Rho (Chen and Sebastian, 2012), its value would be zero as the duration costs nothing.

Proof: The Greeks of a bond are:

$\Delta_{B}=\Gamma_{B}=v_{B}=0$

$\Theta_{B}=\frac{\partial B_{t}}{\partial_{t}}=r B_{t, T}^{\prime}$

$P_{B}=\frac{\partial B_{t}}{\partial_{r}}=-(T-t) B_{t, T} "$

so when we go long or short one bond, the price of Rho $P_{\rho}=0$.

Knowing this, we can compute the cost of the Theta: If we buy a bond that costs $\mathrm{B}_{\mathrm{t}}$ and hedge the rho risk (no cost), our pure theta exposure of $\mathrm{rB}_{\mathrm{t}}$ costs us $B_{t}$, so

$P_{\Theta}=\frac{B_{t, T}}{r B_{t, T}}=\frac{1}{r}$.

Now in order to find the price of Gamma (which is more complex) we are going to look for the price of a delta, rho, and theta hedged call option portfolio denoted as $\mathrm{P}^{\star}$ (Bodie et al., 2010b) which is equivalent as if we said that the portfolio is Gamma neutral:

$$
\begin{aligned}
& P^{*}=C-P_{\Delta} \Delta_{c}-P_{p} p_{c}-P_{\Theta} \Theta_{c} \\
& P^{*}=\left(S N\left(d_{1}\right)-K_{e}^{-r(T-t)} N\left(d_{2}\right)\right)-S N\left(d_{1}\right) \\
& P^{*}=-\frac{1}{r}\left(\frac{-N\left(d_{1}\right) \sigma S}{2 \sqrt{(T-t)}}-r K e^{-r(T-t)} N\left(d_{2}\right)\right. \\
& P^{*}=\frac{N^{\prime}\left(d_{1}\right) \sigma S}{2 r \sqrt{(T-t)}}
\end{aligned}
$$

by using the Black-Scholes formula along with the prices per unit of delta, rho and theta.

So we have:

$$
\begin{gathered}
\Gamma_{p^{*}}=\frac{N^{\prime}\left(d_{1}\right)}{S_{\sigma} \sqrt{(T-t)}} \Delta_{p}^{*}=0, \\
\Theta_{p^{*}}=0 . v_{p}{ }^{*}=\sigma S^{2}(T-t) \Gamma_{c}
\end{gathered}
$$

and

$$
p_{p^{*}}=0 \text {. }
$$

In order to get the price of gamma we have to solve the following equation:

$$
\begin{aligned}
& \frac{p^{*}}{\Gamma_{p^{*}}}=\frac{\frac{N^{\prime}\left(d_{1}\right) \sigma S}{2 r \sqrt{(T-t)}}}{\frac{N^{\prime}\left(d_{1}\right)}{S \sigma \sqrt{(T-t)}}}=\frac{\sigma^{2} S^{2}}{2 r} \\
& p^{*}=\left(\frac{\sigma^{2} S^{2}}{2 r}\right) \Gamma_{p^{*}},
\end{aligned}
$$

it means that $\$ 1$ invested in any delta, rho and theta hedged call would give us the same amount of gamma which is

$$
\Gamma_{p^{*}} / p^{*}=2 r / \sigma^{2} S^{2} \Leftrightarrow P_{\Gamma}=\frac{p^{*}}{\Gamma_{p^{*}}}=\frac{\sigma^{2} S^{2}}{2 r},
$$

To summarize, we have

$$
P_{\Delta}=S, P_{\Gamma}=\frac{\sigma^{2} S^{2}}{2 r}, P_{\rho}=0, P_{v}=0, P_{\Theta}=1 / r,(41)
$$

So the price of any European option (Carter, 2012) $\mathrm{V}$ in terms of its Greeks can be written as:

$$
\begin{aligned}
& V=P_{\Delta} \Delta+P_{\Gamma} \Gamma+P_{\rho} p+P_{v} v+P_{\Theta} \Theta \\
& V=S \Delta+\left(\frac{\sigma^{2} s^{2}}{2 r}\right) \Gamma+\left(\frac{1}{r}\right) \Theta,
\end{aligned}
$$


which is equivalent to:

$$
r V=r S C_{s}+\frac{1}{2} \sigma^{2} S^{2} C_{s s}+C_{t} .
$$

We can see from the above given, that ultimately we get the Black-Scholes partial differential equation (Ianieri, 2009) that governs the price dynamics of any derivative.

\section{CONCLUSION}

The options market is a constantly changing market. In Serbia, it is currently at an initial stage and its main purpose will be to allow investors to hedge the existing positions and minimize the risk exposure. In order to do so, the traders and the hedgers will have to fully understand "Greeks" options which are defined as the quantities that represent sensitivities of the option's price to a particular source of risk. The Greeks are the best tools for building portfolios despite of market conditions. In this paper we offered an insight into risk management options in a straightforward way and we also derived the Greeks from the Black-Scholes model in order to show how they could be used to create strategies that profit from the option's time to maturity, volatility and risk-free interest rate changes. We also provided several real life examples on how the Greeks could lead to a more accurate pricing and trading which will further on alert a hedger to over or undervalued options that could be exploited for a profit.

\section{REFERENCES}

Augen, J. (2008). The volatility edge in options trading: New technical strategies for investing in unstable markets. Upper Saddle River, N.J: FT Press.

Augen, J. (2011). The option trader's workbook: A problemsolving approach. Upper Saddle River, N.J: FT Press.

Black, F., \& Scholes, M. (1972). The valuation of option contracts and a test of market efficiency. The Journal of Finance, 27(2), 399-417. doi:10.1111/j.1540-6261.1972. tb00969.x.

Bodie, Z., Kane, A., \& Marcus, A.J. (2010a). Investments. New York, NY: McGraw-Hill Irwin.

Bodie, Z., Kane, A., \& Marcus, A. J. (2010b). Investments and portfolio management. New York, NY: McGrawHill Irwin.

Bodie, Z., Kane, A., \& Marcus, A.J. (2010c). Student solutions manual for investments. New York, NY: McGrawHill Irwin.
Carter, J.F. (2012). Mastering the trade: Proven techniques for profiting from intraday and swing trading setups. New York: McGraw Hill Professional.

Chen, A.D., \& Sebastian, M. (2012). The option trader's hedge fund: A business framework for trading equity and index options. Upper Saddle River, N.J: FT Press.

Cohen, G. (2005). The bible of options strategies: The definitive guide for practical trading strategies. Upper Saddle River, N.J: FT Prentice Hall.

Cottle, M.C. (2006). Options trading: The hidden reality: Ri\$k Doctor guide to position adjustment and hedging. Chicago: RiskDoctor.

Fontanills, G. (2005). The options course: High profit \& low stress trading methods. Hoboken, N.J: John Wiley \& Sons.

Hull, J.C. (2002). Options, futures, and other derivatives (5th ed.). New York, NY: Prentice Hall College Div.

Hull, J.C. (2011). Student solutions manual for options, futures, and other derivates (8th ed.). Upper Saddle River, N.J: Pearson Prentice Hall.

Jeremić, Z. (2009). Finansijska tržišta. Beograd: Univerzitet Singidunum. (in Serbian).

Jonson, B. (2007). Options trading 101: From theory to application. New York: Morgan James Publishing

Kolb, R. W. (2003). Futures, options and swaps. Malden, MA: Blackwell.

Ianieri, R. (2009). Options theory and trading: A step-by-step guide to control risk and generate profits. Hoboken, N.J: Wiley.

McDonald, R.L. (2009). Derivatives markets. New Jersey: Prentice Hall.

Mullaney, M. (2009). The complete guide to option strategies: Advanced and basic strategies on stocks, ETFs, indexes, and stock indexes. Hoboken, N.J: Wiley.

Natenberg, S. (1994). Option volatility and pricing strategies: Advanced trading techniques for professionals. New York: McGraw-Hill.

Nations, S.B. (2012). Options math for traders: How to pick the best optionstrategies for your market outlook. Hoboken, N.J: Wiley.

Passarelli, D. (2011). The market taker's edge: Insider strategies from the options trading floor. New York: McGrawHill.

Passarelli, D. (2012). Trading option Greeks: How time, volatility, and other pricing factors drive profits. Hoboken, NJ: Wiley.

Ross, S., Westerfield, R., \& Jaffe, J. (2012a). Corporate finance. New York: McGraw-Hill.

Ross, S., Westerfield, R., \& Jaffe, J. (2012b). Solutions manual for corporate finance. New York: McGraw-Hill.

Sincere, M. (2006). Understanding options. New York: McGraw-Hill. 
Vine, S. (2011). Options: Trading strategy and risk management. Hoboken, N.J: Wiley.

Živković, B., \& Šoškić, D. (2007). Finansijska tržišta i institucije. Beograd: Centar za izdavačku delatnost Ekonomskog fakulteta. (in Serbian).

\section{OPCIJE, GREEKS, I UPRAVLJANJE RIZIKOM}

\section{Rezime:}

Opcije su finansijski derivati koji predstavljaju ugovor koji daje pravo vlasniku, ali ne i obavezu, da kupi ili proda određenu aktivu po ugovorenoj ceni izvršenja u toku određenog vremenskog perioda. Derivatni ugovori mogu da dobiju vrednost od skoro svake određene aktive ili čak drugih derivata: postoje opcije na akcije, opcije na obveznice, opcije na svopove, vremenske opcije, prave opcije i mnoge druge. Opcije postoje duži vremenski period, ipak postaju popularne nakon što su Fisher Black, Myron Scholes and Robert Merton razvili teoretski cenovni model poznat kao Black-Scholes model.

Opcije postaju standardizovan produkt trgovine na Čikaškoj berzi opcija (CBOT) posredstvom garancije klirinske kuće. Danas, opcijama se trguje na berzama ili van-berzanski (OTC ) i one se uglavnom koriste za portfolio hedžing i spekulacije.

U ovom naučnom radu akcenat je stavljen na tržišno upravljanje rizikom posmatrano iz ugla trgovaca opcijama, kao i na opis karakteristika rizika plain vanilla Evropskih opcionih ugovora putem "Greeks" kvantitativa, koji predstavljaju opcionu osetljivost na rizik. Na kraju rada konstruisan je portfolio koji će ukloniti navedene rizike.

\section{Ključne reči:}

finansijski derivati, OTC tržište, hedžing, rizik, spekulacije, Black-Scholes model, Greeks.

Received: March 31st, 2014. Correction: April 1st, 2014. Accepted: April 3rd, 2014. 